\title{
Daily mass balance of phosphorus and nitrogen in effluents of production sectors of trout farming system
}

\author{
Balanço de massa diário de fósforo e nitrogênio em efluentes de setores de \\ criação em truticultura
}

Munique de Almeida Bispo Moraes ${ }^{1}$, Clovis Ferreira do Carmo², Carlos Massatoshi Ishikawa ${ }^{2}$, Yara Aiko Tabata ${ }^{3}$ and Cacilda Thais Janson Mercante ${ }^{2}$

${ }^{1}$ Programa de Pós-graduaçáo em Aquicultura e Pesca, Centro de Pesquisa e Desenvolvimento de Recursos Hídricos, Instituto de Pesca, Avenida Francisco Matarazzo, 455, CP 61070,

CEP 05001-900, São Paulo, SP, Brazil

e-mail: muniquebio@gmail.com
${ }^{2}$ Centro de Pesquisa e Desenvolvimento de Recursos Hídricos, Instituto de Pesca, Avenida Francisco Matarazzo, 455, CP 61070, CEP 05001-900, São Paulo, SP, Brazil e-mail: clovis@pesca.sp.gov.br; ishikawa@pesca.sp.gov.br; cthais@pesca.sp.gov.br

${ }^{3}$ Estação Experimental de Salmonicultura, Agência Paulista de Tecnologia dos Agronegócios da Secretaria de Agricultura e Abastecimento do Estado de São Paulo, 361, CEP 12460-000, Campos do Jordão, SP, Brazil e-mail: yara@aquicultura.br

\begin{abstract}
Aim: The mass balance has recently been applied in Brazilian aquaculture. In relation to trout farming, few studies have used this methodology as environmental indicator, especially when considering each development stage of fish. The daily mass balance allows an estimate of nutrients discharge, because the sampling effort over 24 hours enables to monitor the variations throughout the day. This study aimed to identify the breeding sector (fingerlings, juveniles and adults) in trout farming contributes with the great discharge of phosphorus and nitrogen in the effluent. Methods: The concentrations of total phosphorus (TP), orthophosphate $\left(\mathrm{PO}_{4}-\mathrm{P}\right)$, total nitrogen (TN) and ammonium $\left(\mathrm{NH}_{4}-\mathrm{N}\right)$ were determined in affluent and effluents of the production system. The environmental indicators were calculated based on the values of nutrients loads and by quantifying the daily discharge of nutrients from the mass balance method. Results: Over the 24 hours, the trout farming exported an average of $0.26 \mathrm{~kg}$ TP, $0.11 \mathrm{~kg} \mathrm{PO}-\mathrm{P}, 3.11 \mathrm{~kg} \mathrm{TN}$ and $0.18 \mathrm{~kg} \mathrm{NH}_{4}-\mathrm{N}$. The discharge of phosphorus and nitrogen in the effluent was higher at night associated to feeding management (hours and feeding frequency) and the nocturnal habits of trout. The juvenile and adult sectors accounted for the greatest contribution of these nutrients, related the largest fish biomass and metabolism, supported by the feed conversion ratio of 1.95:1 and 2.01:1, respectively. Conclusion: In order to reduce exports of phosphorus and nitrogen there is a need to adequate the feeding management (feeding frequency from two to four times per day according to the trout development stage; carry out feeding in times close at twilight due to the nocturnal habits of this specie; reduce excess of ration offered and use good quality ration considering the distinct nutritional requirements of each trout stage of development). Besides the mass balance, the feed conversion ratio is also an efficient tool to detect the efficiency of feed utilization; therefore, it is proposed its use as environmental indicator, aiming the aquaculture environmental sustainability.
\end{abstract}

Keywords: nutrients loads; mass balance; fingerlings; juveniles; adults.

Resumo: Objetivo: $\mathrm{O}$ balanço de massa tem sido aplicado recentemente na aquicultura brasileira. Em relação à truticultura, poucos trabalhos têm utilizado essa metodologia como indicador ambiental, notadamente quando se considera cada fase de desenvolvimento. $\mathrm{O}$ balanço de massa diário permite a estimativa da descarga de nutrientes, pois o esforço amostral ao longo de 24 horas possibilita monitorar as oscilaçóes ao longo do dia. O objetivo deste estudo foi identificar o setor de criação em truticultura (alevinos, juvenis e adultos) que contribui com o maior aporte de fósforo e nitrogênio no efluente. Métodos: As concentraçóes de fósforo total (PT), ortofosfato $\left(\mathrm{P}-\mathrm{PO}_{4}\right)$, nitrogênio 
total (NT) e íon amônio $\left(\mathrm{N}-\mathrm{NH}_{4}\right)$ foram determinadas no afluente e nos efluentes do sistema de produçáo. Os indicadores ambientais foram calculados com base nos valores das cargas de nutrientes e por meio de quantificação da descarga diária de nutrientes pelo método de balanço de massa. Resultados: No decorrer de 24 horas, a truticultura exportou em média $0,26 \mathrm{~kg}$ PT, 0,11 kg P-PO $4,3,11 \mathrm{~kg} \mathrm{NT} \mathrm{e} \mathrm{0,18} \mathrm{kg} \mathrm{N-NH} 4$. A descarga de fósforo e nitrogênio no efluente foi mais elevada durante o período noturno, associada aos horários e frequência de arraçoamento e ao hábito noturno das trutas. O balanço de massa mostra que os setores de juvenis e adultos foram responsáveis pelo maior aporte desses nutrientes, relacionados à maior biomassa de peixes e metabolismo, corroborado pela taxa de conversão alimentar de 1,95:1 e 2,01:1, respectivamente. Conclusáo: Para reduzir as exportaçóes de fósforo e nitrogênio há necessidade de adequar o manejo alimentar (frequência alimentar de duas a quatro vezes por dia considerando o estágio de desenvolvimento da truta; realizar alimentação em horários próximos ao crepúsculo devido ao hábito noturno da espécie; reduzir o excesso de ração oferecida e usar ração de boa qualidade considerando as exigências nutricionais distintas de cada estágio de desenvolvimento da truta). Além do balanço de massa, a taxa de conversão alimentar também é ferramenta eficiente para detectar a eficiência de utilização da ração. Portanto, propóe-se a sua utilização como indicador ambiental, visando à sustentabilidade ambiental da aquicultura.

Palavras-chave: carga de nutrientes; balanço de massa; alevinos; juvenis; adultos.

\section{Introduction}

The rainbow trout (Oncorhynchus mykiss Walbaum, 1792) is one of the most studied and cultivated species in the world for its ability to survive and reproduce both in natural environments as well as in captivity, in addition to its high commercial value (FAO, 2011).

In Brazil, between 2008 and 2010, there was a $40 \%$ increase in the trout production, from 3,662.6 tons in 2008 to $5,122.7$ tons in 2010 (Brasil, 2012). In 2011, there was reduction in the trout production $(3,277.2$ tons) due to incentive to produce native fish, especially the tambaqui production, but the trout also was one of the species featured in national aquaculture production (Brasil, 2013).

Rainbow trout is produced in all states of the South and Southeast of Brazil, limited to altitude zones, because these areas have mild temperatures and well oxygenated waters, essential features for its cultivation. However, these regions are located in areas of environmental preservation with the presence of water sources and rivers of first order, oligotrophic water bodies, characterized by low concentrations of nutrients and, according to Bond et al. (2014), more vulnerable to external disturbances. These disorders are related to the deterioration of water quality, especially in intensive fish production systems, such as trout farming. This question refers not only to the animals' needs in farming, but also the quality of water that is dumped in the water receiving body (Barak $\&$ van Rijn, 2000), because changes in water quality are associated mainly to the increase of organic waste, especially phosphorus, released in the effluents. The aquaculture effluents have potential for eutrophication of continental water and degradation of aquatic ecosystems (Araripe et al., 2006; Koçer et al., 2013).

The main factor related to this excessive discharge of waste in the effluent is the feed introduced in the production system (Bureau et al., 2003; Wang et al., 2012). It be directly by dispersion of not-eaten food/undigested (solid) or the metabolic products generated by organisms (dissolved), such as ammonia and orthophosphate, which are excreted mainly by the gills and kidneys (Bergheim $\&$ Brinker, 2003). The generation of these wastes is determined by genetics, age, and size of fish, environmental factors, supply frequency and quality of food offered to organisms (Boaventura et al., 1997; Frasca-Scorvo et al., 2013).

The food is the main factor related to excessive discharge of waste in the effluent, however, in Brazil, there is no legislation that considers the nutrient content in its composition as a proposal for reducing this discharge. The National Environmental Council (CONAMA), federal collegiate of the Environment Ministry, provides for the classification of water bodies and environmental guidelines for its framing, and establishes the conditions and standards of the effluent discharge by resolutions 357 of 2005 and 430 of 2011. These Resolutions only regulates the allowed limit of nutrient concentrations in effluent discarded according to the framework of the water body (Brasil, 2005, 2011). 
Most discussions on aquaculture activities and the environment involve identifying impacts and the definition of "sustainable aquaculture". However, the question should not be how environmental sustainability is defined, but how it can be measured (Boyd et al., 2007). In raceways (system used in trout farming), the water flow frequently is known, the nutrient concentrations may be easily converted into loads and, from the difference between the input and output of the system, the nutrient mass balance can be calculated (Bartoli et al., 2007).

Mass balances in fish farming reported in the literature has shown high degree of nutrient discharge into the natural environment that can cause major impacts in oligotrophic systems (Bartoli et al., 2007; Araújo-Silva et al., 2014; Caramel et al., 2014). This methodology has recently been applied in Brazilian aquaculture (Araújo-Silva et al., 2014; Mercante et al., 2014). Regarding trout farming, few studies have used the mass balance as environmental indicator (Caramel et al., 2014), especially when considering each fish development. The most studies of fingerling, juvenile and adult trout focuses on the areas of hematology, nutrition and growth (Karabulut et al., 2010; Tahmasebi-Kohyani et al., 2011). In addition, through study performed in trout farming it has been found a need to identify the sector that contributes most to the supply of nutrients in the effluent (Caramel et al., 2014).

According to Bartoli et al. (2007), the daily mass balance allows an accurate estimate of nutrients inputs, because of the sampling effort over 24 hours allows monitoring the fluctuations throughout the day. Thus, this study aimed to identify the breeding sector (fingerlings, juveniles and adults) in trout farming that contributes with the great discharge of phosphorus and nitrogen in the effluent by quantifying the daily discharge of nutrients from the mass balance method.

\section{Materials and Methods}

The present study was performed in intensive trout farming system, located in National Park of Serra da Bocaina, $35 \mathrm{~km}$ away from Bananal city, São Paulo State (SP), Brazil, in Hydrographic Basin Paraíba do Sul situated 1,160 meters above sea level $\left(22^{\circ} 50^{\prime} 03,92^{\prime \prime} \mathrm{S}\right.$ and $\left.44^{\circ} 25^{\prime} 46,33^{\prime \prime} \mathrm{W}\right)$. Atlantic forest area covering large part of the springs that provide potable water to the population, located in tropical and subtropical region, in the mountainous regions where temperatures are close to $22^{\circ} \mathrm{C}$ in the hottest month.
The system used for the rearing of rainbow trout (Oncorhynchus mykiss Walbaum, 1792) was raceway characterized by intensive production with high continuous water flow. The trout farming system was populated with 24,100 fish at different stages of development distributed in twelve masonry tanks ( $1.0 \mathrm{~m}$ deep; 4 tanks of $2 \mathrm{~m}^{3} ; 4$ tanks of $5 \mathrm{~m}^{3}$ and 4 tanks of $19 \mathrm{~m}^{3}$ ) and separated into three sectors of production (Figure 1). The trout farming studied received constant flow of water with average water flow of $4.13 \mathrm{~L} \mathrm{~s}^{-1}$ in fingerlings sector $\left(\mathrm{E}_{\mathrm{F}}\right)$, 16.87 $\mathrm{L} \mathrm{s}^{-1}$ in juveniles sector $\left(\mathrm{E}_{\mathrm{J}}\right)$ and $19.15 \mathrm{~L} \mathrm{~s}^{-1}$ in adults sector $\left(\mathrm{E}_{\mathrm{A}}\right)$.

The feeding was performed by the producer three times daily (08:00h, 14:00h and 20:00h) with extruded ration containing $40 \%$ of crude protein in all farming sectors. Considering the stages of development of the individuals and an estimated total biomass in each sector of the production system (39 kg - fingerlings sector; $196 \mathrm{~kg}$ - juveniles sector; and $332 \mathrm{~kg}$ - adults sector) the producer determined the daily amount of feed for each sector $(0.7 \mathrm{~kg}$ - fingerlings; $4.0 \mathrm{~kg}$ - juveniles; and $7.5 \mathrm{~kg}$ - adults). The total biomass in each sector of production was estimated through weekly biometrics. The feed conversion ratio (FCR) was calculated in each sector of the production system.

The analysis were performed every 3 hours in four distinct sites, beginning at 10:00 h on 25 November 2012 and with end at 07:00h on 26 November 2012, characterizing a nictemeral assessment, with total of eight collected samples. The distribution of sampling sites (Figure 1)



Figure 1. Schematic drawing of the trout farming system located in the Serra da Bocaina (SP), organized into three sectors, with the number of individuals and the average weight, where: $A_{S}$ (affluent of the production system); $\mathrm{E}_{\mathrm{F}}$ (effluent of the fingerlings sector); $\mathrm{E}_{\mathrm{J}}$ (effluent of the juveniles sector); $\mathrm{E}_{\mathrm{A}}$ (effluent of the adults sector); arrows $=$ directional flow of water in the production system. 
followed the order: $A_{S}-$ affluent of the production system; $\mathrm{E}_{\mathrm{F}}$ - effluent of the fingerlings sector; $\mathrm{E}_{\mathrm{J}}$ - effluent of the juveniles sector and $\mathrm{E}_{\mathrm{A}}$ - effluent of the adults sector.

In the field were analyzed the variables $\mathrm{pH}$, dissolved oxygen (DO) $\left(\mathrm{mg} \mathrm{L}^{-1}\right)$ and water temperature $(\mathrm{Temp})\left({ }^{\circ} \mathrm{C}\right)$ with multiparameter probe Horiba U53G model. The calculation of the percentage of saturation $(\% \mathrm{DO})$ was carried out from the concentrations of dissolved oxygen, water temperature and altitude of the studied area. Water samples were collected in the subsurface water column. Samples for analysis of the totals (phosphorus and nitrogen) were frozen. Samples for analysis of dissolved fraction were immediately filtered in vacuum pump using GFF Whatman filters with porosity of $0.47 \mu \mathrm{m}$ and after they were frozen. In the laboratory, the samples were analyzed for concentration of total phosphorus (TP) $\left(\mu \mathrm{g} \mathrm{L}^{-1}\right)$ and total nitrogen (TN) ( $\left.\mu \mathrm{g} \mathrm{L}^{-1}\right)$ according to the methodology described by Valderrama (1981), orthophosphate $\left(\mathrm{PO}_{4}^{-}-\mathrm{P}\right)\left(\mu \mathrm{g} \mathrm{L}^{-1}\right)$ according to the methodology described by Strickland \& Parsons (1960) and ammonium $\left(\mathrm{NH}_{4}-\mathrm{N}\right)\left(\mu \mathrm{g} \mathrm{L}^{-1}\right)$ according to the methodology described by APHA et al. (2005). To calculate the water flows $\left(\mathrm{L} \mathrm{s}^{-1}\right)$ were used the volumetric method (Leopoldo \& Sousa, 1979) and the float method (Marques \& Argento, 1988).

To interpret the effects of physical and chemical variables monitored during the experiment, the data after $\log$ transformation $(x+1)$ were analyzed using the Kruskal-Wallis test followed by the Student-Newman-Keuls test (SNK) to verify the spatial variations (Zar, 2010). The adopted significance level was 0.05 . To check the degree of importance and the joint effect of the measured variables ( $\mathrm{pH}, \% \mathrm{DO}$, Temp, PT, P-PO, NT and $\mathrm{N}-\mathrm{NH}_{4}$ ) was performed the Principal Component Analysis (PCA) (Manly, 2008). The correlation of the variables with the axes was considered representative when above 0.5 .

The values of dissolved oxygen $\left(\mathrm{mg} \mathrm{L}^{-1}\right)$ and the concentrations of nutrients $\left(\mu \mathrm{g} \mathrm{L}^{-1}\right)\left(\mathrm{TP}, \mathrm{PO}_{4}-\mathrm{P}\right.$, $\mathrm{TN}$ and $\mathrm{NH}_{4}-\mathrm{N}$ ) in affluent and in effluent from the different sectors of trout faming system were multiplied by the water flow $\left(\mathrm{L} \mathrm{s}^{-1}\right)$ to obtain the value of loads $\left(\mathrm{kg} \mathrm{dia}^{-1}\right)$, through the following equation (Equation 1):

$\mathrm{L}=[] \times \mathrm{W}_{\mathrm{F}}$

where $\mathrm{L}=$ loads of TP, $\mathrm{PO}_{4}-\mathrm{P}, \mathrm{TN}$ and $\mathrm{NH}_{4}-\mathrm{N}\left(\mathrm{kg} \mathrm{d}^{-1}\right)$, [ ] = nutrient concentrations $\left(\mu \mathrm{g} \mathrm{L}^{-1}\right), \mathrm{W}_{\mathrm{F}}=$ water flow $\left(\mathrm{L} \mathrm{s}^{-1}\right)$.
The commercial feed used in trout farming system contained $1.0 \%(0.010 \mathrm{~kg})$ of phosphorus and $4.0 \%(0.040 \mathrm{~kg})$ of nitrogen per $\mathrm{kg}$ of feed. The nutrient load of production system via feeding was estimated by the amount of phosphorus and nitrogen contained in the total feed offered, through the following equation (Equation 2):

$\mathrm{I}_{\mathrm{F}}=\mathrm{F}_{\mathrm{O}} \times \mathrm{N}_{\mathrm{F}}$

where $I_{F}=$ input of nutrient via feed $\left(\mathrm{kg} \mathrm{day}^{-1}\right.$ of $\mathrm{P}$ or $\mathrm{N}), \mathrm{F}_{\mathrm{O}}=$ amount of feed offered $\left(\mathrm{kg} \mathrm{day}^{-1}\right)$, $\mathrm{N}_{\mathrm{F}}=$ amount of nutrient $(\mathrm{kg})$ by kilogram of feed.

To quantify the amount of waste generated by the trout farming activity was calculated the daily mass balance by nutrient load that released via effluent and subtracted from the affluent of the system (nutrients in the water and the amount of nutrients contained in the total feed offered), through the following equation (Equation 3):

$\mathrm{MB}_{\mathrm{L}}=\mathrm{L}_{\mathrm{E}}-\mathrm{L}_{\mathrm{A}}$

where $\mathrm{MB}_{\mathrm{L}}=$ mass balance among loads of TP, $\mathrm{PO}_{4}-\mathrm{P}, \mathrm{TN}$ and $\mathrm{NH}_{4}-\mathrm{N}\left(\mathrm{kg} \mathrm{d}^{-1}\right), \mathrm{L}_{\mathrm{E}}=$ the considered variable load in the effluent of the system $\left(\mathrm{kg} \mathrm{d}^{-1}\right)$, $\mathrm{L}_{\mathrm{A}}=$ the considered variable load in the affluent of the system $\left(\mathrm{kg} \mathrm{d}^{-1}\right)$.

\section{Results}

The variables saturation percentage of oxygen $(\mathrm{H}=21.56 ; \mathrm{P}<0.001)$ and water temperature $(\mathrm{H}=9.58 ; \mathrm{P}=0.023)$ varied significantly among sites, being that the greatest values were obtained in the affluent $\left(\mathrm{A}_{\mathrm{S}}\right)$, while the $\mathrm{pH}$ was similar in all sampling sites. Regarding total phosphorus $(\mathrm{H}=54.79 ; \mathrm{P}<0.001)$, orthophosphate $(\mathrm{H}=50.81$; $\mathrm{P}<0.001)$, total nitrogen $(\mathrm{H}=29.26 ; \mathrm{P}<0.001)$ and ammonium $(\mathrm{H}=28.59 ; \mathrm{P}<0.001)$, there was a significantly increase from the affluent $\left(A_{S}\right)$ to the effluents of the production system $\left(\mathrm{E}_{\mathrm{F}}, \mathrm{E}_{\mathrm{J}}\right.$ and $\left.\mathrm{E}_{\mathrm{A}}\right)$, being that the greatest concentrations were obtained in the juveniles and adults sectors (Table 1).

The Figure 2 shows the daily variation of $\mathrm{pH}$, saturation percentage of dissolved oxygen and water temperature in the production system, variables associated to the welfare of trout. Although $\mathrm{pH}$ has remained slightly acidic in all sectors of the production system, throughout the day was observed fluctuations with higher values between 10:00 and 16:00 hours and lower values at night. The highest saturation percentages of dissolved oxygen and the lowest values of water temperature were obtained between 19:00 and 07:00 hours. 
Table 1. Mean and confidence interval (95\%) of the analyzed variables throughout the day (24 hours) in the trout farming system.

\begin{tabular}{|c|c|c|c|c|c|}
\hline \multirow{2}{*}{ Variables } & \multicolumn{4}{|c|}{ Sites } & \multirow{2}{*}{ Reference values } \\
\hline & $A_{s}$ & $E_{F}$ & $E_{J}$ & $E_{A}$ & \\
\hline $\mathrm{pH}$ & $6.83^{\mathrm{a}} \pm 0.33$ & $6.88^{\mathrm{a}} \pm 0.23$ & $6.61^{\mathrm{a}} \pm 0.13$ & $6.71^{\mathrm{a}} \pm 0.25$ & $6.00-9.00^{*}$ \\
\hline$\%$ Sat DO & $129.82^{\mathrm{a}} \pm 2.82$ & $124.58^{\mathrm{b}} \pm 2.00$ & $121.13^{c} \pm 1.69$ & $122.22^{\mathrm{bc}} \pm 1.83$ & $\geq 80.00^{*}$ \\
\hline $\mathrm{T}\left({ }^{\circ} \mathrm{C}\right)$ & $14.35^{a} \pm 0.42$ & $13.82^{\mathrm{ac}} \pm 0.21$ & $13.67^{b c} \pm 0.17$ & $13.66^{b c} \pm 0.16$ & $\leq 20.00^{*}$ \\
\hline $\operatorname{TP}\left(\mu \mathrm{g} \mathrm{L}^{-1}\right)$ & $13.66^{a} \pm 2.30$ & $34.05^{b} \pm 5.40$ & $78.95^{\circ} \pm 11.54$ & $109.80^{\circ} \pm 11.21$ & $\leq 100.00^{\star *}$ \\
\hline $\mathrm{PO}_{4}-\mathrm{P}\left(\mu \mathrm{g} \mathrm{L}^{-1}\right)$ & $4.49^{a} \pm 1.31$ & $8.26^{\mathrm{a}} \pm 3.83$ & $31.80^{\mathrm{b}} \pm 4.50$ & $46.16^{b} \pm 4.72$ & - \\
\hline $\mathrm{TN}\left(\mathrm{mg} \mathrm{L}^{-1}\right)$ & $2.05^{a} \pm 0.24$ & $2.53^{b} \pm 0.24$ & $3.02^{c} \pm 0.19$ & $3.00^{\complement} \pm 0.31$ & $\leq 2.18^{\star *}$ \\
\hline $\mathrm{NH}_{4}-\mathrm{N}\left(\mu \mathrm{g} \mathrm{L}^{-1}\right)$ & $115.37^{a} \pm 6.73$ & $134.74^{b} \pm 9.51$ & $182.87^{\complement} \pm 27.01$ & $161.31^{c} \pm 13.85$ & $\begin{array}{c}\leq 3,700.00 \mathrm{se} \\
\mathrm{pH} \leq 7.5^{* *}\end{array}$ \\
\hline
\end{tabular}

$\mathrm{A}_{\mathrm{S}}=$ affluent of the production system; $\mathrm{E}_{\mathrm{F}}=$ effluent of the fingerlings sector; $\mathrm{E}_{\mathrm{J}}=$ effluent of the juveniles; $\mathrm{E}_{\mathrm{A}}=$ effluent of the adults sector; \% Sat $\mathrm{OD}=$ saturation percentage of oxygen dissolved; $\mathrm{T}$ = water temperature; $\mathrm{TP}=$ total phosphorus; $\mathrm{PO}_{4}-\mathrm{P}=$ orthophosphate; $\mathrm{TN}=$ total nitrogen; $\mathrm{NH}_{4}-\mathrm{N}=$ ammonium. Means followed by the same letter in the line do not differ by the SNK test (0.05). Reference values in the last column. *FAO (2011); ${ }^{* *}$ Brasil (2005).
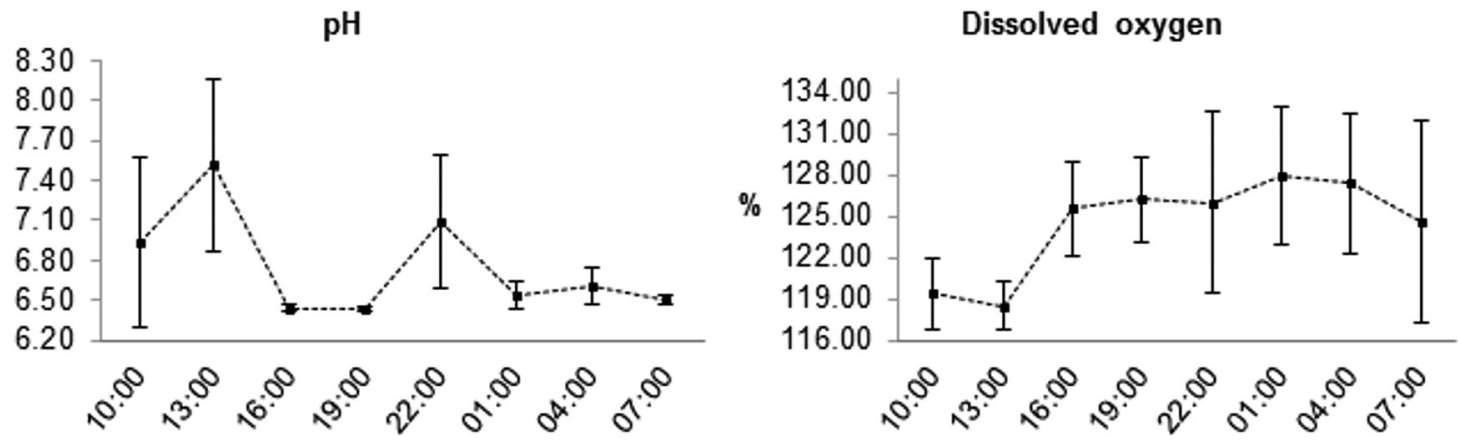

Water temperature

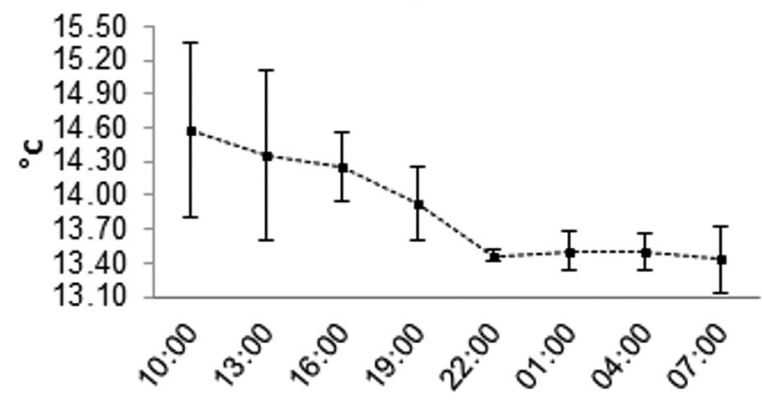

Figure 2. Average daily variation and standard deviation of $\mathrm{pH}$, dissolved oxygen $(\%)$ and water temperature $\left({ }^{\circ} \mathrm{C}\right)$ in the trout farming system, considering the three sectors of production.

The Principal Component Analysis summarized in its first two components $76.64 \%$ of the total variability of the data analyzed (Figure 3 ) (Table 2). The axis $1(52.12 \%)$ summarized the differences among sectors. On the negative side of the axis 1 there are the sampling units related to affluent and fingerlings sector, associated to the higher saturation percentages of dissolved oxygen. On the positive side of the axis 1 there are the sampling units related to juveniles and adults sectors, associated to the higher concentrations of phosphorus and nitrogen that occurred between 22:00 and 07:00 hours.

The axis $2(24.52 \%)$ summarized, mainly, the differences among the collection times. On the positive side of the axis 2 there are the sampling units of the samplings performed between 10:00, 13:00 and 16:00 hours, associated to the higher values of $\mathrm{pH}$ and water temperature. On the negative side of the axis 2 there are the sampling units related to the samplings performed between 19:00 and 07:00 hours, associated to the higher 


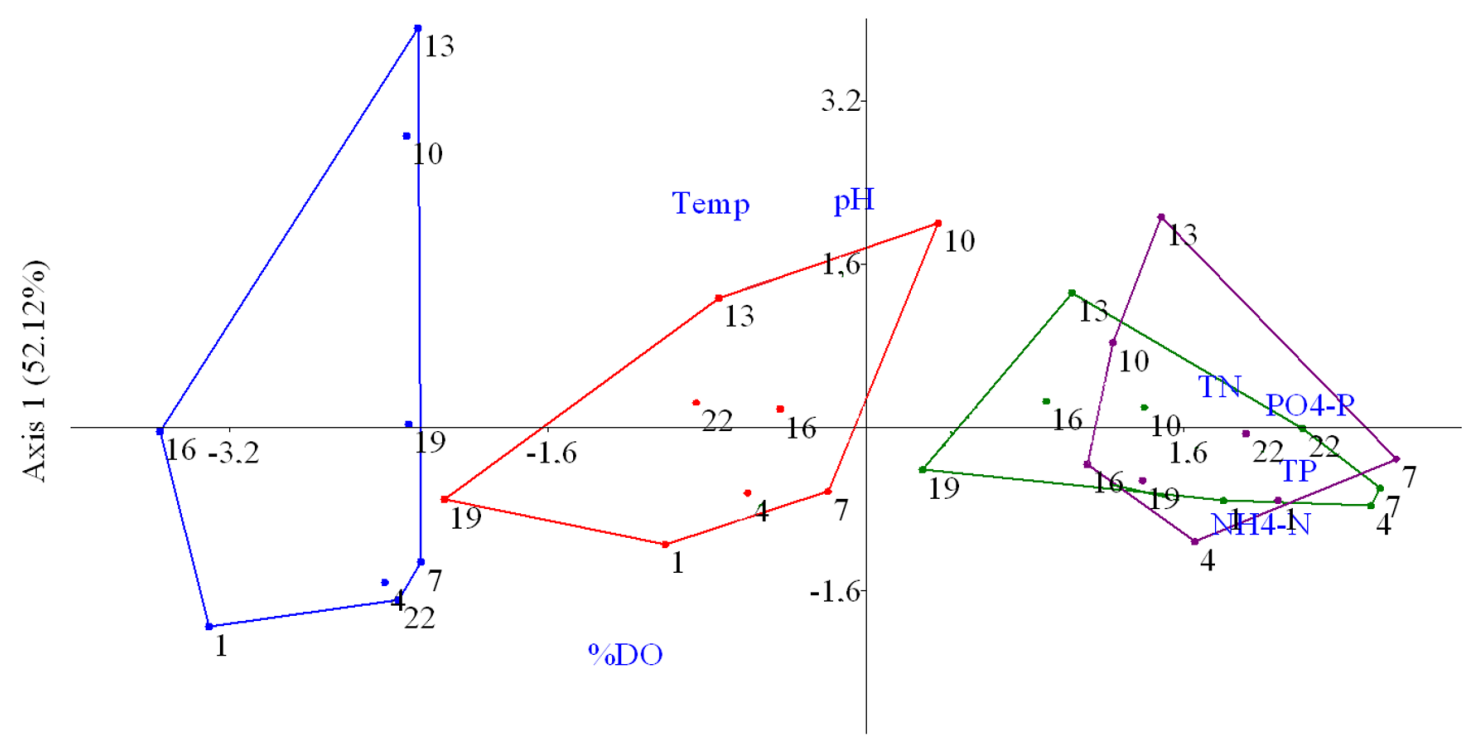

Axis $2(24.52 \%)$

Figure 3. Ordination biplot by Principal Component Analysis (PCA) of the sample units generated from seven environmental variables. Where: the hours of collection correspond to the numbers $10(10: 00 \mathrm{~h}), 13(13: 00 \mathrm{~h})$, 16 (16:00h), 19 (19:00h), $22(22: 00 \mathrm{~h}), 1(01: 00 \mathrm{~h}), 4(04: 00 \mathrm{~h})$ and 7 (07:00h); the lines (convex hull) join the cloud represented by the hours in which the samples were taken at each point: affluent (blue), fingerlings (red), juveniles (green) and adults (purple); Temp = water temperature; $\% \mathrm{DO}=$ saturation percentage of dissolved oxygen; $\mathrm{TP}=$ total phosphorus; $\mathrm{PO}_{4}-\mathrm{P}=$ orthophosphate; $\mathrm{TN}=$ total nitrogen; $\mathrm{NH}_{4}-\mathrm{N}=$ ammonium.

Table 2. Pearson correlation coefficients between the variables and the first two axes of PCA (bold values correspond to the variables that had the greatest correlation with the axes, above 0.5 ).

\begin{tabular}{lccc}
\hline \multirow{1}{*}{ Variables } & & \multicolumn{2}{c}{$\begin{array}{c}\text { Principal } \\
\text { components }\end{array}$} \\
\cline { 3 - 4 } & Abbreviations & Axis 1 & Axis 2 \\
\hline DH & & -0.087 & $\mathbf{0 . 7 7 2}$ \\
Wissolved oxygen & $\% \mathrm{DO}$ & $-\mathbf{0 . 6 6 3}$ & $\mathbf{- 0 . 6 5 1}$ \\
Total phosphorus & $\mathrm{Temp}$ & -0.467 & $\mathbf{0 . 7 6 0}$ \\
Orthophosphate & $\mathrm{TP}$ & $\mathbf{0 . 9 5 3}$ & -0.077 \\
Total nitrogen & $\mathrm{PO}_{4}-\mathrm{P}$ & $\mathbf{0 . 9 2 4}$ & 0.125 \\
Ammonium & $\mathrm{TN}$ & $\mathbf{0 . 7 6 4}$ & 0.187 \\
& $\mathrm{NH}_{4}-\mathrm{N}$ & $\mathbf{0 . 7 9 6}$ & -0.245 \\
& Explicability & $\mathbf{5 2 . 1 2 \%}$ & $\mathbf{2 4 . 5 2 \%}$ \\
\hline
\end{tabular}

saturation percentages of dissolved oxygen. The discharge of phosphorus and nitrogen in the effluent was higher during the night and the juveniles and adults sectors accounted for the greatest contribution of these nutrients.

Of the total feed offered in the fingerlings sector $(0.6 \mathrm{~kg}), 0.006 \mathrm{~kg}$ were available as $P$ and $0.02 \mathrm{~kg}$ as $\mathrm{N}$. In the juveniles sector, of the total feed offered (4 kg), $0.040 \mathrm{~kg}$ were available as $\mathrm{P}$ and $0.16 \mathrm{~kg}$ as N. Whereas in the adults sector, from $7.5 \mathrm{~kg}$ of feed offered, $0.075 \mathrm{~kg}$ were available as $\mathrm{P}$ and
$0.30 \mathrm{~kg}$ as $\mathrm{N}$. When the phosphorus and nitrogen loads were calculated stood out the contribution of total phosphorus, orthophosphate, total nitrogen and ammonium in effluent of the all sectors of the production. The mass balance calculations showed that the trout farming system exported nutrients over 24 hours of research. Regarding the values of dissolved oxygen, there was a reduction due to the consumption and breathing processes (Table 3) (Figure 4).

\section{Discussion}

Considering the recommended values for the physical and chemical variables in monitoring of the water quality for trout production, the results showed acceptable values of $\mathrm{pH}$, dissolved oxygen and water temperature in all sectors (FAO, 2011). Although the $\mathrm{pH}$ has remained slightly acidic, throughout the day was observed fluctuations with higher values between 10:00 and 16:00 hours and lower values during the night (Figure 2). The daily variations in $\mathrm{pH}$ may cause stress in organisms, even if the absolute value is within the tolerance range (Ceccarelli et al., 2000), interfering with productivity. These oscillations can be related mainly with the respiratory process of the cultured organisms, because in lotic systems 

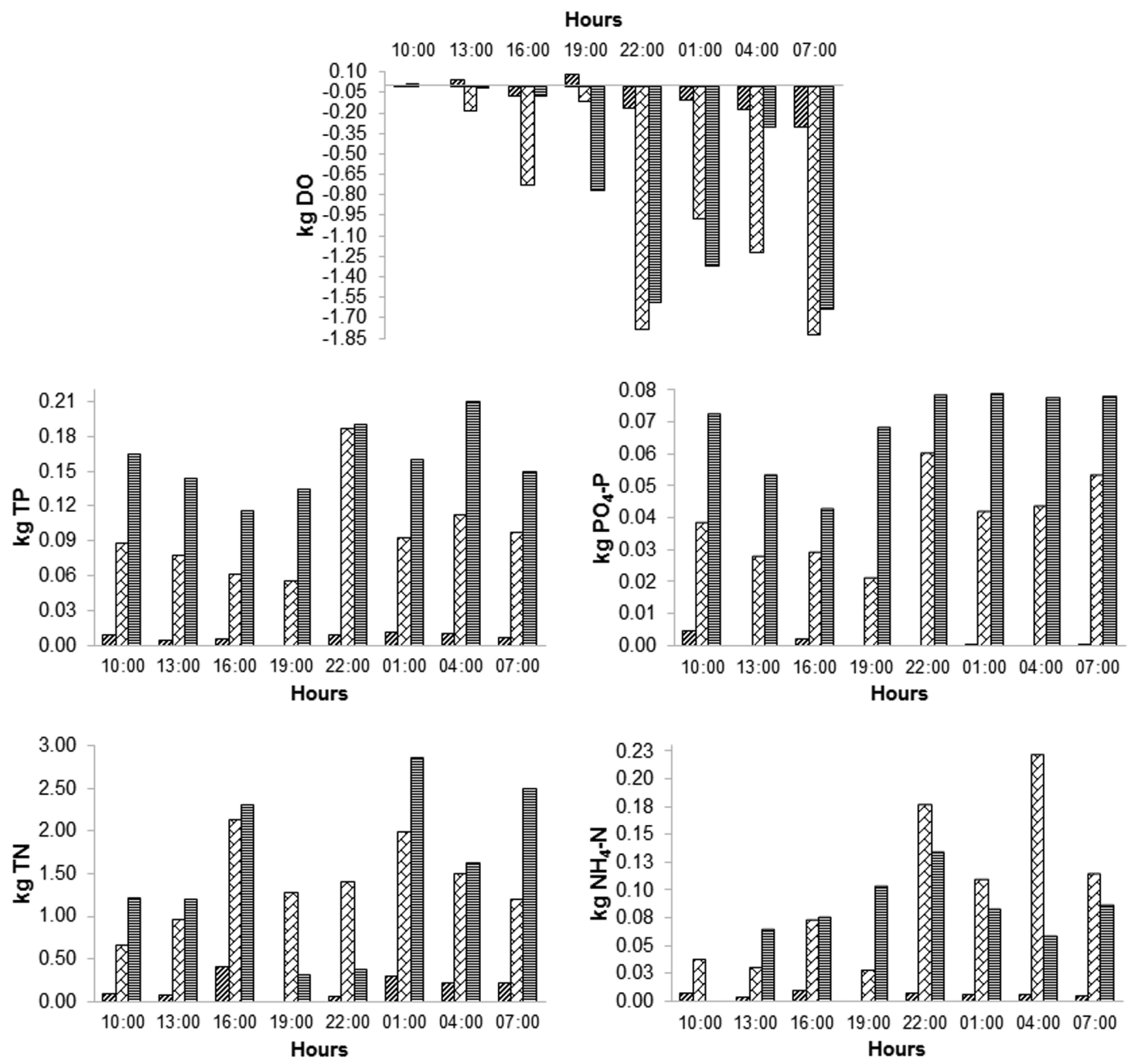

■Fingerlings $\square$ Juveniles 目Adults

Figure 4. Daily mass balance $(\mathrm{kg})$ of dissolved oxygen $(\mathrm{DO})$, total phosphorus $(\mathrm{TP})$, orthophosphate $\left(\mathrm{PO}_{4}-\mathrm{P}\right)$, total nitrogen $(\mathrm{TN})$ and ammonium $\left(\mathrm{NH}_{4}-\mathrm{N}\right)$ in the three sectors of the trout farming system.

Table 3. Daily mass balance $\left(\mathrm{D}_{\mathrm{MB}}\right)$ (mean values) of dissolved oxygen (DO), total phosphorus (TP), orthophosphate $\left(\mathrm{PO}_{4}-\mathrm{P}\right)$, total nitrogen $(\mathrm{TN})$ and ammonium $\left(\mathrm{NH}_{4}-\mathrm{N}\right)$ in the sectors of the trout farming system. In the last line is the mean value of the daily mass balance $\left(\mathrm{D}_{M B}\right)$ of the trout faming system.

\begin{tabular}{|c|c|c|c|c|c|c|}
\hline & & $\begin{array}{c}\text { DO } \\
\left(\mathrm{kg} \mathrm{dia}^{-1}\right)\end{array}$ & $\begin{array}{c}\text { TP } \\
\left(\mathrm{kg} \mathrm{dia}^{-1}\right)\end{array}$ & $\begin{array}{c}\mathrm{PO}_{4}-\mathrm{P} \\
\left(\mathrm{kg} \mathrm{dia}^{-1}\right)\end{array}$ & $\begin{array}{c}\mathrm{TN} \\
\left(\mathrm{kg} \mathrm{dia}^{-1}\right)\end{array}$ & $\begin{array}{c}\mathrm{NH}_{4}-\mathrm{N} \\
\left(\mathrm{kg} \mathrm{dia}^{-1}\right)\end{array}$ \\
\hline \multirow[t]{3}{*}{ Fingerlings } & Affluent & 4.13 & 0.011 & 0.002 & 0.75 & 0.04 \\
\hline & Effluent & 4.04 & 0,012 & 0.003 & 0.90 & 0.05 \\
\hline & $\mathrm{D}_{\text {мв }}$ & -0.09 & 0.001 & 0.001 & 0.15 & 0.01 \\
\hline \multirow[t]{3}{*}{ Juveniles } & Affluent & 16.79 & 0.060 & 0.007 & 3.16 & 0.17 \\
\hline & Effluent & 15.94 & 0.116 & 0.046 & 4.39 & 0.27 \\
\hline & $D_{M B}$ & -0.85 & 0.056 & 0.039 & 1.23 & 0.10 \\
\hline \multirow[t]{3}{*}{ Adults } & Affluent & 18.99 & 0.098 & 0.008 & 3.71 & 0.19 \\
\hline & Effluent & 18.28 & 0,181 & 0.076 & 4.96 & 0.27 \\
\hline & $D_{M B}$ & -0.71 & 0.083 & 0.068 & 1.25 & 0.08 \\
\hline Trout farming & $D_{M B}$ & -1.65 & 0.140 & 0.108 & 2.63 & 0.18 \\
\hline
\end{tabular}


like as trout farming, continuous renewal of the water decreases the residence time of water in the system and consequently hinders the permanence of phytoplankton (Boyd \& Queiroz, 2001). A different situation occurs in lentic systems, such as in the production of tilapia in excavated ponds, where primary production is a major factor related to the variations over the day (Rodrigues et al., 2010; Mercante et al., 2011).

The largest saturation percentages of dissolved oxygen were obtained in the affluent and fingerlings sector (Table 1), while the highest consumption occurred in the juveniles sector (Table 3) (Figure 4) due to higher stocking density and the highest rate of feeding (Araripe et al., 2006; Bartoli et al., 2007). Throughout the day, the highest saturation percentages of dissolved oxygen were obtained in samplings performed between 19:00 and 07:00 hours (Figures 2 and 3), associated mainly to decreased water temperature. However, it was in this period that occurred the higher oxygen consumption (Figure 4), because the trout are more active at night (Young, 1999; Cooke et al., 2000).

The discharge of phosphorus and nitrogen in the effluents may vary depending on the quality of food and nutrition strategy (Tello et al., 2010). In Brazil, it is common to use feeds using alternative and conventional foods of vegetal origin, as cottonseed meal, sunflower meal, peanut meal, among others, in replacement of soybean meal and fishmeal, to reduce production costs (Abimorad et al., 2012). However, these minerals present about $70 \%$ or more of phosphorus, which cannot be fully absorbed and may increase the amount of nutrients released via effluent. One way to reduce the waste production arising aquaculture can be based on nutritional strategies, as in the formulation of the feed and the development of efficient feeding systems based on energy requirements of the species (Bouwman et al., 2013).

The discharge of the ammonium and orthophosphate is primarily associated to fish metabolic activity, while the discharge of phosphorus and nitrogen is associated to the non-ingested food and the elimination of feces (Bartoli et al., 2007). The highest concentrations of nutrients were obtained in effluent from juvenile and adult sectors, fact probably associated to higher stocking density, the increase in the amount of feed and the fish metabolism as observed by other authors (Bartoli et al., 2007; Koçer et al., 2013). The recommended limit of nitrogen in the current legislation has been exceeded in the three breeding sectors, while values above the phosphorus recommended by the legislation were obtained in effluent of the adult sector (Brasil, 2005), evidencing the inadequate food management.

The concentrations of nutrients in effluents ranged over 24 hours. This variation can be associated mainly to feeding frequency, feeding schedules and fish metabolism (Bureau et al., 2003; Wang et al., 2012). The nutrients, especially the ammonium, begin to be excreted after approximately four hours of feed intake (Brett \& Zala, 1975), which may explain the nutrients excretion peaks observed in the present study after that time interval. The nutrient excretion in rainbow trout is higher at night (Coloso et al., 2003) due to metabolism and crepuscular habit (Young, 1999; Cooke et al., 2000), situation observed in the effluent of the three breeding sectors between 22:00 and 07:00 hours, and may be related to feeding management.

In order to improve the performance of fish in the assimilation of feed nutrients, it must be considered the proper management recommended feeding rate up to four times daily for fingerlings due to more rapid growth and low ability to store food (smaller digestive system when compared to juveniles and adults). In the case of juveniles and adults, reduce the daily frequency of food for two times, due to the ability to store food (FAO, 2011; Frasca-Scorvo et al., 2013). In addition, should choose the hours according to the fish's metabolism, because trout has peaks of feeding at dawn and dusk (Yamamoto et al., 2002; Shima et al., 2003).

Although all sectors have been characterized as nutrient exporters, the largest loads were obtained in juvenile and adult sectors. These results may be related to the size of fish. Smaller fish generally have better-feed efficiency when compared to larger fish due to more rapid growth (Einen \& Roem, 1997). Feed conversion ratio of $1.54: 1$ in the fingerlings sector against the FCR of 1.95:1 and 2.01:1 in the juveniles and adults sector, respectively, supports this statement. The adult sector accounted for the largest discharge of total phosphorus, orthophosphate and total nitrogen, while the juvenile sector accounted for the largest export ammonium due to higher biomass of fish. Juveniles excrete more ammonia due to the high growth rate (Bartoli et al., 2007; Dumas et al., 2010), which results in greater metabolic activity of this stage of development.

The assimilation of TP and TN from diet by rainbow trout is relatively low (Coloso et al., 2001), therefore, the high levels of these nutrients 
were observed in the effluents. Probably, originated from faecal waste and metabolites. Considering the final weight of the trouts in fingerlings sector $(20 \mathrm{~g})$, in the juveniles sector $(180 \mathrm{~g})$ and in the adults sector $(250 \mathrm{~g})$, as the content of the TP and TN trout decreases with increase in body weight it is suggested that dietary needs of these nutrients are higher in the early stages as compared to adults (Hernàndez et al., 2004). However, the feed used in the breeding sectors had the same amount of phosphorus and nitrogen (1\% TP and 4\% TN per $\mathrm{kg}$ feed), which may explain the increased discharge of these nutrients in the adult sector due to its low assimilation.

Regarding the orthophosphate, the export was lower when compared to other nutrients in all sectors. This result may be related to the fact that a significant amount of this nutrient leaching of the feed in short time (Reid \& Moccia, 2006).

The quantification of daily mass balance of nutrients shows that trout farming is an exporter of nutrients, especially the sectors of juvenile and adult, related the largest fish biomass and metabolism, supported by the feed conversion ratio (1.95:1 and 2.01:1, respectively). The largest nutrient discharge detected at night is associated to feeding management (hours and frequency of feeding) and nocturnal habit of the trout. As the water bodies characterized by low nitrogen and phosphorus concentrations are more vulnerable to external disturbances, as in the stream that receives the effluents of this production system, it is necessary to apply practices in order to reduce of the excessive discharge of these nutrients, through adjustments in feeding management (feeding frequency from two to four times per day according to the trout stage of development; carry out feeding in times close at twilight due to the nocturnal habits of this specie; reduce excess of ration offered and use good quality ration considering the distinct nutritional requirements of each trout stage of development). Besides the mass balance, the feed conversion ratio is also an efficient tool to detect the efficiency of feed utilization; therefore, it is proposed its use as environmental indicator, aiming the aquaculture environmental sustainability.

\section{Acknowledgements}

The authors thank FAPESP by the financial support no. 2010/07658-3 and Dr. Marcos Guilherme Rigolino, Scientific Researcher at the Experimental Station of Trout Farming, in memoriam, by participation in the analysis of results.

\section{References}

ABIMORAD, E.G., GONÇALVES, G.S. and CASTELLANI, D. A crise dos alimentos e os reflexos na aquicultura brasileira. Pesquisa e Tecnologia, 2012, 9(2), 1-4.

AMERICAN PUBLIC HEALTH ASSOCIATION - APHA, AMERICAN WATER WORKS ASSOCIATION - AWWA and WATER POLLUTION CONTROL FEDERATION WPCF. Standard Methods for the examination of Water and Wastewater. 21 th ed. Washington: APHA, 2005, 1085 p.

ARARIPE, M.N.B.A., GRANÇA SEGUNDO, L.F.F., LOPES, J.B. and ARARIPE, H.G.A. Efeito do cultivo de peixes em tanques rede sobre o aporte de fósforo para o ambiente. Revista Cientifica de Produção Animal, 2006, 8(2), 56-65.

ARAÚJO-SILVA, S.L., MORAES, M.A.B., CARMO, C.F., OSTI, J.A.S., VAZ-DOS-SANTOS, A.M. and MERCANTE, C.T.J. Effluent of a polyculture system (tilapias and shrimps): assessment by mass balance of nitrogen and phosphorus. Journal of Environmental Protection, 2014, 5, 799-804. http:// dx.doi.org/10.4236/jep.2014.510081.

BARAK, Y. and VAN RIJN, J. Biological phosphate removal in a prototype recirculating aquaculture treatment system. Aquacultural Engineering, 2000, 22(1-2), 121-136. http://dx.doi.org/10.1016/S01448609(00)00036-4.

BARTOLI, M., NIZZOLI, D., LONGHI, D., LAINI, A. and VIAROLI, P. Impact of a trout farm on the water quality of an Apennine Creek from daily budgets of nutrients. Chemistry and Ecology, 2007, 23(1), 1-11. http://dx.doi.org/10.1080/02757540601084003.

BERGHEIM, A. and BRINKER, A. Effluent treatment for flow through systems and European environmental regulations. Aquacultural Engineering, 2003, 27(1), 61-77. http://dx.doi.org/10.1016/ S0144-8609(02)00041-9.

BOAVENTURA, R., PEDRO, A.M., COIMBRA, J. and LENCASTRE, E. Trout farm effluents: characterization and impact on the receiving streams. Environmental Pollution, 1997, 95(3), 379-387. http://dx.doi.org/10.1016/S0269-7491(96)00117-0. PMid:15093453.

BOND, T., SEAR, D. and SYKES, T. Estimating the contribution of in-stream cattle faeces deposits to nutrient loading in an English Chalk stream. Agricultural Water Management, 2014, 131, 156-162. http://dx.doi.org/10.1016/j.agwat.2013.08.015.

BOUWMAN, A.F., BEUSEN, A.H.W., OVERBEEK, C.C., BUREAU, D.P., PAWLOWSKI, M. and GLIBERT, P.M. Hindcasts and future projections of global inland and coastal nitrogen and phosphorus loads due to finfish aquaculture. Reviews in Fisheries 
Science, 2013, 21(2), 112-156. http://dx.doi.org/10 .1080/10641262.2013.790340.

BOYD, C.E. and QUEIROZ, J. Feasibility of retention structure, settling basins and best management practices in effluent regulation for Alabama channel catfish farming. Reviews in Fisheries Science, 2001, 9(2), 43-67. http://dx.doi.org/10.1080/20016491101708.

BOYD, C.E., TUCKER, C., MCNEVIN, A., BOSTICK, K. and CLAY, J. Indicators of resource use efficiency and environmental performance in fish and crustacean aquaculture. Reviews in Fisheries Science, 2007, 15(4), 327-360. http://dx.doi. org/10.1080/10641260701624177.

BRASIL. Ministério do Desenvolvimento Urbano e Meio Ambiente. Conselho Nacional do Meio Ambiente CONAMA. Resolução no 357, de 17 de março de 2005. Diário Oficial da República Federativa do Brasil, Brasília, DF, 18 mar. 2005.

BRASIL. Ministério do Desenvolvimento Urbano e Meio Ambiente. Conselho Nacional do Meio Ambiente - CONAMA. Resoluçáo no. 430 de 13 de maio de 2011. Diário Oficial da República Federativa do Brasil, Brasília, DF, 16 maio 2011.

BRASIL. Ministério da Pesca e Aquicultura. Boletim estatístico da pesca e aquicultura: Brasil 2010. Brasília: Ministério da Pesca e Aquicultura, 2012.

BRASIL. Ministério da Pesca e Aquicultura. Boletim estatístico da pesca e aquicultura: Brasil 2011. Brasília: Ministério da Pesca e Aquicultura, 2013.

BRETT, J.R. and ZALA, C.A. Daily pattern of nitrogen excretion and oxygen consumption of sockeye salmon (Oncorhynchus nerka) under controlled conditions. Journal of the Fisheries Research Board of Canada, 1975, 32(12), 2479-2486. http://dx.doi. org/10.1139/f75-285.

BUREAU, D.P., GUNTHER, S.J. and CHO, C.Y. Chemical composition and preliminary theoretical estimates of waste outputs of rainbow trout reared in commercial cage culture operations in Ontario. North American Journal of Aquaculture, 2003, 65(1), 33-38. http://dx.doi.org/10.1577/15488454(2003)065<0033:CCAPTE>2.0.CO;2.

CARAMEL, B.P., MORAES, M.A.B., CARMO, C.F., VAZ-DOS-SANTOS, A.M., TABATA, Y.A., OSTI, J.A.S., ISHIKAWA, C.M., CERQUEIRA, M.A.S. and MERCANTE, C.T.J. Water quality assessment of a trout farming effluent, Bocaina, Brazil. Journal of Water Resource and Protection, 2014, 6(10), 909915. http://dx.doi.org/10.4236/jwarp.2014.610086.

CECCARELLI, P.S., SENHORINI, J.A. and VOLPATO, G.L. Dicas em piscicultura; perguntas e respostas. Botucatu: Santa Gráfica Editora, 2000, $274 \mathrm{p}$.

COLOSO, R.M., BASANTES, S.P., KING, K., HENDRIX, M.A., FLETCHER, J.W., WEIS, P. and FERRARIS, R.P. Effect of dietary phosphorus and vitamin $\mathrm{D}_{3}$ on phosphorus levels in effluent from the experimental culture of rainbow trout (Oncorhynchus mykiss). Aquaculture, 2001, 202(1-2), 145-161. http://dx.doi.org/10.1016/S0044-8486(01)00572-5.

COLOSO, R.M., KING, K., FLETCHER, J.W., HENDRIX, M.A., SUBRAMANYAM, M. and WEIS, P. Phosphorus utilization in rainbow trout (Oncorhynchus mykiss) fed practical diets and its consequences on effluent phosphorus levels. Aquaculture, 2003, 220(1-4), 801-820. http://dx.doi. org/10.1016/S0044-8486(02)00403-9.

COOKE, S.J., CHANDROO, K.P., BEDDOW, T.A., MOCCIA, R.D. and MCKINLEY, R.S. Swimming activity and energetic expenditure of captive rainbow trout Oncorhynchus mykiss (Walbaum) estimated by eletroyogram telemetry. Aquaculture Research, 2000, 31(6), 495-505. http://dx.doi.org/10.1046/j.13652109.2000.00470.x.

DUMAS, A., FRANCE, J. and BUREAU, D. Modelling growth and body composition in fish nutrition: where have we been and where are we going? Aquaculture Research, 2010, 41(2), 161-181. http://dx.doi. org/10.1111/j.1365-2109.2009.02323.x.

EINEN, O. and ROEM, A.J. Dietary protein/energy ratios for Atlantic salmon in relation to fish size: growth, feed utilization and slaughter quality. Aquaculture Nutrition, 1997, 3(2), 115-126. http:// dx.doi.org/10.1046/j.1365-2095.1997.00084.x.

FOOD AND AGRICULTURE ORGANIZATION OF THE UNITED NATION - FAO. Small-scale rainbow trout farming. Rome: FAO, 2011, 92 p.

FRASCA-SCORVO, C.M.D., SCORVO-FILHO, J.D. and ALVES, J.M.C. Manejo alimentar e tanques rede. Pesquisa \& Tecnologia, 2013, 10(2), 1-7.

HERNÁNDEZ, A., SATOH, S., KIRON, V. and WATANABE, T. Phosphorus retention efficiency in rainbow trout fed diets with low fish meal and alternative protein ingredients. Fisheries Science, 2004, 70(4), 580-586. http://dx.doi.org/10.1111/ j.1444-2906.2004.00844.x.

KARABULUT, H.A., YANDI, I. and ARAS, N.M. Effects of different feed and temperature conditions on growth, meat yield, survival rate, feed conversion ratio and condition factor in rainbow trout (Oncorhynchus mykiss) fingerlings. Journal of Animal and Veterinary Advances, 2010, 9(22), 2818-2823. http://dx.doi. org/10.3923/javaa.2010.2818.2823.

KOÇER, M.A.T., KANYILMAZ, M., YILAYAZ, A. and SEVGILI, H. Waste loading into a regulated stream from land-based trout farms. Aquaculture Environment Interactions, 2013, 3(3), 187-195. http://dx.doi.org/10.3354/aei00059.

LEOPOLDO, P.R. and SOUSA, A.P. Hidrometria. Botucatu: UNESP, 1979.

MANLY, B.J.F. Métodos estatísticos multivariados: uma introdução. Porto Alegre: Bookman, 2008, 229 p. 
MARQUES, J.S. and ARGENTO, M.S.F. O uso de flutuadores para avaliação da vazão de canais fluviais. Geociências, 1988, 7, 173-186.

MERCANTE, C.T.J., CARMO, C.F., RODRIGUES, C.J., OSTI, J.A.S., MAINARDES-PINTO, C.S., VAZ-DOS-SANTOS, A.M., TUCCI, A. and DI GENARO, A.C. Limnologia de viveiro de tilápias do nilo: avaliação diurna visando boas práticas de manejo. Boletim do Instituto de Pesca, 2011, 37(1), 73-84.

MERCANTE, C.T.J., VAZ-DOS-SANTOS, A.M., MORAES, M.A.B., PEREIRA, J.S. and LOMBARDI, J.V. Bullfrog (Lithobates catesbeianus) farming system: water quality and environmental changes. Acta Limnologica Brasiliensia, 2014, 26(1), 9-17. http://dx.doi.org/10.1590/S2179975X2014000100003.

REID, G.K. and MOCCIA, R.D. Diel fluctuation of soluble phosphorus in the tank water of rainbow trout, Oncorhynchus mykiss (Walbaum), and relationships with feed inputs and dissolved oxygen. Aquaculture Research, 2006, 37(15), 1606-1610. http://dx.doi. org/10.1111/j.1365-2109.2006.01596.x.

RODRIGUES, C.J., MERCANTE, C.T.J., CARMO, C.F., TUCCI, A., OSTI, J.A.S. and DI GENARO, A.C. Diurnal dynamic of inorganic carbon and oxygen dissolved in a Nile tilapia (Oreochromis niloticus Linnaeus, 1758) fish pond, São Paulo, Brasil. Acta Limnologica Brasiliensia, 2010, 22(4), 466-473. http://dx.doi.org/10.4322/actalb.2011.010.

SHIMA, T., YAMAMOTO, T., FURUITA, H. and SUZUKI, N. Effect of the response interval of selffeeders on the self-regulation of feed demand by rainbow trout (Oncorhynchus mykiss) fry. Aquaculture, 2003, 224(1-4), 181-191. http://dx.doi.org/10.1016/ S0044-8486(03)00219-9.

STRICKILAND, J.D.H. and PARSONS, T.R. $A$ manual of sea water analysis. 2nd ed. Ottawa: Fisheries Research Board of Canada, 1960, 203 p. Bulletin, 125.

TAHMASEBI-KOHYANI, A., KEYVANSHOKOOH, S., NEMATOLLAHI, A., MAHMOUDI, N. and
PASHA-ZANOOSI, H. Dietary administration of nucleotides to enhance growth, humoral immune responses, and disease resistance of the rainbow trout (Oncorhynchus mykiss) fingerlings. Fish \& Shellfish Immunology, 2011, 30(1), 189-193. http://dx.doi. org/10.1016/j.fsi.2010.10.005. PMid:20955799.

TELLO, A., CORNER, R.A. and TELFER, T.C. How do land-based salmonid farms affect stream ecology? Environmental Pollution, 2010, 158(5), 1147-1158. http://dx.doi.org/10.1016/j.envpol.2009.11.029. PMid:20036452.

VALDERRAMA, J.C. The simultaneous analysis of total nitrogen and phosphorus in natural water. Marine Chemistry, 1981, 10(2), 109-122.

WANG, X., OLSEN, L.M., REITAN, K.I. and OLSEN, Y. Discharge of nutrient wastes from salmon farms: environmental effects, and potential for integrated multi-trophic aquaculture. Aquaculture Environment Interactions, 2012, 2(3), 267-283. http://dx.doi. org/10.3354/aei00044.

YAMAMOTO, T., SHIMA, T., FURUITA, H. and SUZUKI, N. Influence of feeding diets with and without fish meal by hand and by self-feeders on feed intake, growth and nutrient utilization of juvenile rainbow trout (Oncorhynchus mykiss). Aquaculture, 2002, 214(1-4), 289-305. http://dx.doi. org/10.1016/S0044-8486(02)00035-2.

YOUNG, M.K. Summer diel activity and movement of adult brown trout in high elevation streams in Wyoming, U.S.A. Journal of Fish Biology, 1999, 54, 181-189.

ZAR, J.H. Biostatistical analysis. 5th ed. New Jersey: Pearson Prentice Hall, 2010, 944 p.

Received: 04 May 2015 Accepted: 18 November 2015 